\title{
Preliminary Evidence on the Validity of the Brazilian Short Work Attachment Measure - SWAM Version
}

\author{
Alexsandro Luiz De Andrade ${ }^{1}$ (iD \\ Rosana Suemi Tokumaru ${ }^{1}$ \\ Michael Leiter ${ }^{2}$
}

\begin{abstract}
There is growing interest on the relationship between attachment and work- or career-related decisions. However, to this date, there are no scientific reports assessing adult attachment in work environment in Brazilian samples. This study aimed to adapt and collect psychometric evidence from the Short Work Attachment Measure for Brazilian Portuguese. A total of 450 adults (62.2\% women; mean age $=23.8$ years old) from a Southeastern state of Brazil participated in this research. Exploratory and confirmatory factorial procedures replicated the original version of the two-dimensional structure of the measure. The McDonald's Omega accuracy indicators were higher than 0.78 for the instrument. Evidence of convergent validity was observed with a measure of attachment to romantic relationships and life satisfaction. We concluded that the Brazilian version of SWAM presents adequate psychometric properties
\end{abstract}

Keywords: attachment behavior, scales, work relations in management, test construction, psychometry

\section{Evidências Preliminares de Validade da Versão Brasileira da Short Work Attachment Measure - SWAM}

\begin{abstract}
Resumo: Há um crescente interesse na relação entre apego e decisões relacionadas a trabalho e carreira. Entretanto, até o presente momento, não há relatos científicos de nenhuma medida para avaliação do apego adulto no contexto laboral em amostras brasileira. O presente estudo teve por objetivo adaptar e levantar evidências psicométricas da Short Work Attachment Measure para o português brasileiro. Participaram da pesquisa 450 profissionais adultos $(62,2 \%$ feminino, $M=23,8$ anos) oriundas de um estado do sudeste brasileiro. Procedimentos fatoriais exploratórios e confirmatórios replicaram a versão original da estrutura bidimensional da medida. Os indicadores de precisão ômega de McDonald's do instrumento foram ambos superiores a 0,78. Evidências de validade convergente foram observadas com uma medida de apego para relações românticas e satisfação com a vida. Conclui-se que a versão brasileira da SWAM apresenta propriedades psicométricas adequadas.
\end{abstract}

Palavras-chave: comportamento de apego, escalas, relações de trabalho na administração, construção de testes, psicometria

\section{Evidencias Preliminares de la Validez de la Versión Brasileña de Short Work Attachment Measure - SWAM}

\begin{abstract}
Resumen: Existe un creciente interés en la relación entre apego y decisiones relacionadas con el trabajo y la carrera. Pero hasta el momento son inexistentes los estudios científicos sobre medidas que evalúan el apego adulto en el contexto laboral en muestras brasileñas. El presente estudio tuvo como objetivo adaptar y recopilar evidencias psicométricas de la Short Work Attachment Measure para el portugués brasileño. Participaron 450 profesionales adultos en la investigación (el $62,2 \%$ mujeres, $M=23,8$ años), provenientes de un estado del Sudeste de Brasil. Los procedimientos factoriales exploratorios y confirmatorios se replicaron a la versión original de la estructura bidimensional de la medida. Los indicadores de precisión omega de McDonald's del instrumento fueron superiores a 0,78 . Se observó evidencias de validez convergente con una medida de apego a las relaciones románticas y de satisfacción con la vida. Se concluye que la versión brasileña de SWAM tiene propiedades psicométricas adecuadas.
\end{abstract}

Palabras clave: comportamiento de apego, escalas, relaciones laborales en la administración, elaboración de pruebas, psicometría

${ }^{1}$ Universidade Federal do Espirito Santo, Vitória-ES, Brazil

${ }^{2}$ Deakin University, Geelong, Australia

Financial support: CNPQ (The National Council for Scientific and Technological Development); FAPES (Foundation of Support to Research and Innovation of Espírito Santo).

Correspondence address: Alexsandro Luiz De Andrade. Universidade Federal do Espírito Santo. Av. Fernando Ferrari, 514 - Goiabeiras, VitóriaES, Brazil. CEP 29.075-910. E-mail: alexsandro.deandrade@yahoo.com
Since Bowlby's seminal work (Bowlby, 1973), attachment styles have been central to understand the construction and maintenance of interpersonal relationships (Fraley \& Shaver, 2000; Hazan \& Shaver, 1990). The attachment theory was firstly proposed to explain infant's behavior of seeking and maintaining closeness to primary caregivers, especially in stressful situations (Bowlby, 1973). 
Caregivers' response to infant behaviors promote the development of different attachment styles in an adaptive manner. For example, in the presence of inconsistent caregivers a child may develop an anxious attachment style. Children with this attachment style may present more fearful behavior in strange environment. Such behavior can be adaptive, since the child cannot trust that the caregiver will be protective in this situation (Bowlby, 1973).

Considering the adaptive role of the attachment styles built in childhood, there are demonstrations that this attachment are fairly stable throughout life and affect different aspects of adult life as romantic, family and work relationships, health, and career outcomes (Fraley \& Shaver, 2000; Hatfield \& Rapson, 2010; Hayden, Mullauer, \& Andreas, 2017; Poteat, Shockley, \& Allen, 2015; Reizer, 2015; Vignoli, Croity-Belz, Chapeland, de Fillipis, \& Garcia, 2005). The construct is often studied in the typological dimensions of anxious, avoidant, and secure attachment (Brennan, Clark, \& Shaver, 1998). People with an anxious attachment style typically present negative selfimage, they are fearful of rejection and abandonment, and are also concerned with relationships. Avoidantly attached individuals have a negative view of others, leading to interpersonal distancing, discomfort with intimacy, and independence. Securely attached individuals have positive self-image and trust others, which leads to positive behaviors of interpersonal proximity, comfort with intimacy and less concern with being rejected by the other (Brennan et al., 1998; Hazan \& Shaver, 1990; Leiter, Day, \& Price, 2015; Richards \& Schat, 2011). Although insecure attachment has been correlated with negative personal and relational traits, anxious and avoidant attachment styles are not negative per se, they are adaptive forms of interaction (Bowlby, 1973).

In the last two decades a growing interest to understand the influence of attachment over career outcomes and interpersonal relationships at work has occurred (Richards \& Schat, 2011; Yip, Ehrhardt, Black, \& Walker, 2018). Theoretical models applied to interpersonal relationships in management and work environment demonstrate that attachment construct is related to the burnout syndrome (Leiter, Day, et al., 2015), civility and wellbeing (Leiter, Peck, \& Gumuchian, 2015), stress (Johnstone \& Feeney, 2015), work-family conflict (Sumer \& Knight, 2001), mentoring (Poteat et al., 2015), satisfaction (Reizer, 2015), and organizational commitment (Byrne, Albert, Manning, \& Desir, 2017). Attachment theory also explains how interpersonal relationships with coworkers affect organizational processes (Hazan \& Shaver, 1990; Yip et al., 2018).

Considering interpersonal relationships in work environment, individuals with anxious and avoidant attachment styles are more concerned with their coworkers' rejection (Hazan \& Shaver, 1990) and they reported lower levels of job and life satisfaction (Ramos \& Lopez, 2018; Reizer, 2015). Anxious attachment style was positively correlated with burnout, while avoidant attachment presented negative relationship with civility, trust, and leadership (Leiter, Day, et al., 2015; Leiter,
Peck et al., 2015). On the other hand, secure attachment was positively correlated with job satisfaction, competence, and comfort in the presence of co-workers (Hazan \& Shaver, 1990; Leiter, Day, et al., 2015).

Attachment is a distinct and relevant construct for understanding people's experiences and interactions in work environment (Byrne et al., 2017; Harms, 2011; Yip et al., 2018).In a survey with healthcare providers, the researchers concluded that individual attachment styles play a key role in building quality social relationships at workplace (Leiter, Day, et al., 2015). They emphasize the practical implications that recognizing attachment styles in team workers may have for designing interventions to prepare group members and managements to deal with differences, generating a healthier work environment. Byrne et al. (2017) found that both anxiety and avoidance were negatively related to engagement at work and they also emphasize that these findings have practical implications in the organizational level. They suggest that the creation of a fair and inclusive work environment may produce psychological safety that could positively affect anxiety and avoidance, amplifying work engagement. The results reviewed demonstrate the significance of the workers' attachment styles evaluation to understand interpersonal relationships at the workplace, the development of adequate strategies of relationship management and the promotion of health in work environment. Identification of attachment styles at work may also have practical implications to workers global health and well-being. Negative relation between anxious and avoidant attachment styles and life satisfaction was used as indication of this effect (Ramos \& Lopez, 2018; Reizer, 2015).

\section{Measures of attachment and the Short Work Attachment Measure (SWAM)}

According to Ravitz, Maunder, Hunter, Sthankiya, and Lancee (2010) several measures to assess attachment styles in adults exist, ranging from interviews (Hesse, 1999) to psychometric scales (Garbarino, 1998). In a dimensional perspective, more traditional measures assess attachment with two or three dimensional models. The Adult Attachment Scale (AAS) is an example of measure that assesses attachment using three independent attachment dimensions: secure attachment, insecure avoidant attachment, and insecure anxious/ambivalent attachment (Collins, 1996; Collins \& Read, 1990). Recently, attachment has been operationalized mainly as self-report scales based on two-dimensional model of insecure attachment (Fraley, Hudson, Heffernan, \& Segal, 2015).

Frequently, these self-report scales use the hierarchical model of two dimensions that characterize insecure attachment - anxiety and avoidance (Brennan et al., 1998). Secure attachment dimension is also evaluated in these measures as low scores occur in both dimensions of insecurity. 
In Brazil, until the elaboration of this paper, three measures of attachment with evidence of validity and precision for the Brazilian context were found, all based on the Experience in Close Relationships Inventory (Brennan et al, 1998), presenting items focused on family, romantic, and friendship contexts (Natividade \& Shiramizu, 2015; Rocha, Peixoto, Nakano, Motta, \& Wiethaeuper, 2017; Shiramizu, Natividade, \& Lopes, 2013).

One of the major criticisms about applying attachment theory to the work environment is that items or questions in the measures are operationalized to investigate family, friendship, and romantic relationships (Fraley et al., 2015). Leiter, Day, et al. (2015) developed the Short Workplace Attachment Measure (SWAM) to address these limitations and broaden the research agenda regarding attachment role in the organizational context. SWAM is a self-report scale for adult attachment evaluation that specifically refers to interpersonal relationships at work. The measure was originally developed in English, based on the adaptation of items from measures that use the two-dimensional structure of insecure attachment (anxious and avoidant styles). The validation process was carried out with Canadian health professionals and, data analysis of the measure included exploratory and confirmatory factor analysis. Factor analysis resulted in the expected two-dimensional structured, referring to the aspects of insecure attachment (first factor) and avoidance (second factor). The instrument accuracy was adequate, presenting Cronbach's alpha coefficient of 0.78 for both factors. Evidence of convergent validity of the instrument was found with dimensions of Burnout (cynicism and emotional exhaustion) and evidence of divergent validity was found with positive aspects at work (civility, trust, and organizational support). The final instrument consists of 10 items and it was already used to investigate the relations among attachment at work and burnout (Leiter, Day, et al., 2015) and attachment at work, incivility and wellbeing (Leiter, Peck, et al., 2015).

Considering the importance of attachment theory in the understanding of interpersonal relationships and their outcomes in several contexts and the recent interest in studying these phenomena in workplace (Johnstone \& Feeney, 2015; Yip et al., 2018) our study aims to adapt and to show psychometric evidence of SWAM in a Brazilian sample. To our knowledge, measures specifically designed to the workplace context in Brazilian Portuguese, were not tested until the elaboration of this paper.

The development of a valid instrument for assessing attachment in the workplace in the Brazilian context presents great potential for the study of interpersonal relations at work. Yip et al. (2018) indicate the possibilities of these studies ranging from mapping of workers' attachment styles, influence of attachment styles on different outcomes and the effect of attachment styles on dyadic, group, and organizational relationships, to the possibility of management and intervention on the attachment styles, aiming at the increase of the well-being in the workplace and at the general performance of the workers.

\section{Method}

\section{Participants}

A total of 450 adults from a Southeastern Brazilian state participated in this study. Most participants were female (280; 62.2\%). Participants' mean age was 23.8 years old $(S D=6.7$ years). Most participants $(355 ; 78.9 \%)$ reported incomplete higher education, followed by 58 (12.9\%) who had complete higher education or postgraduate education and $37(8.2 \%)$ who did not answer this question. In this study, all participants should be, at least, 18 years old and also been active in the labor market.

\section{Instruments}

SWAM Portuguese Brazilian version. Firstly, we contacted the authors of SWAM and requested authorization to adapt the instrument to Brazilian Portuguese. After receiving the authorization, two bilingual research experts in the field of psychometry and evolutionary psychology, performed the translation and retro translation of the 10 items of the original scale. A third expert in psychometry, native speaker in English, compared the retro translated version with the original one and found no semantic differences between them. The Brazilian Portuguese adapted version was submitted to five participants, with the aimed sample profile, to test the semantic comprehension and clarity of items. The resulting version is presented in Table 1.

The instrument presented to the participants was composed of different psychological scales and sociodemographic questions characterizing the sample (e.g. sex, age, state of residence, educational level and careerrelated questions). The scales used in this study were: (a) The Brazilian Portuguese version of the Short Workplace Attachment Measure (SWAM, Table 1); (b) Experience in Close Relationship Scale (ECR - short Version) (Natividade \& Shiramizu, 2015), a 10 item 5-point Likert type scale $(1-$ not at all like me/ 5 - very much like me) that evaluate romantic attachment. It comprised two subscales: anxiety $-\alpha=.73$ (i.e. Often, I think that my partner does not want as much emotional proximity/closeness as I would like) and avoidance $-\alpha=.73$ (i.e. Generally, I try to avoid a lot of emotional closeness with my partner); (c) Life Satisfaction Scale (Zanon, Bardagi, Layous, \& Hutz, 2014), a 5 item 5-point Likert type scale (1-strongly disagree/ 5-strongly agree) that evaluate life satisfaction $-\alpha=.89$ (ex: My life is, in almost everything, as I wish it to be).

The instruments ECR and Life Satisfaction Scale were used to verify external convergent and divergent validity of SWAM. These constructs and instruments were chosen because they have already demonstrated evidence of validity in the Brazilian context (Natividade \& Shiramizu, 2015; Zanon et al., 2014). Besides, although these measures focus on general aspects of relationships and life satisfaction, the literature presents some results that demonstrate significant correlations among these constructs and attachment styles at 
the workplace (Leiter, Day, et al., 2015; Ramos \& Lopez, 2018; Reizer, 2015).

Table 1

Original (English) and adapted (Brazilian Portuguese) SWAM items

Original item Adapted item

Anxious attachment style at the workplace

Eu me preocupo de não ser

I worry that others don't value valorizado pelos meus colegas me as much as I value them. de trabalho da mesma forma que os valorizo.

I worry that I won't measure up to other people at work.

Eu me preocupo em não corresponder as expectativas das outras pessoas no trabalho.

I fear that friends at work will let me down.

Others are often reluctant to be as close as I would prefer at work.

Eu tenho medo que os meus colegas de trabalho não me ajudem quando eu precisar

Meus colegas de trabalho com frequência não são tão próximos quanto eu gostaria

I'm afraid to reveal too much Tenho medo de me abrir muito about myself to people at work. para meus colegas de trabalho.

Avoidant attachment style at the workplace

I make close friendships at work. (R)

I like to have close personal relationships with people at work. (R)

A close friendship is a necessary part of a good working relationship. (R)

I work hard at developing close working relationships. (R)

I don't need close friendships at work.

Costumo ter amigos próximos no trabalho (R)

Eu gosto de ter relações próximas com pessoas com quem trabalho $(\mathrm{R})$

Acredito que amizade é uma parte necessária de uma boa relação de trabalho. (R)

Esforço-me para desenvolver boas relações interpessoais com meus colegas de trabalho. (R)

Não sinto necessidade de ter amigos próximos no trabalho.

\section{Procedure}

Data collection. Participants were recruited with an adaptation of the CORP collection method (Wachelke, Natividade, Andrade, Wolter, \& Camargo, 2014). Researchers contacted companies and organizations of higher education by e-mail and telephone. After obtaining the companies' consent a trained research assistant personally contacted employees at their workplace to explain the research objectives and collect e-mail addresses of those interested to participate in the research. Then, personalized e-mails invitations were sent to these prospective participants with a link to the questionnaire. The average response time was 15 minutes.

Data analysis. Data from the 450 participants were randomly separated in two equal samples. Structural validity of the adapted instrument was assessed using an exploratory factor analysis conducted with one

sample (225 participants) followed by a confirmatory factor analysis conducted with the other sample (225 participants). McDonald's Omega coefficient was used to evaluate the final precision of the instrument (Dunn, Baguley, \& Brunsden, 2014; Trizano-Hermosilla \& Alvarado, 2016). Finally, Pearson correlations were performed using all data to verify convergent validity of SWAM with external variables (attachment style and life satisfaction). Data were treated in software R (R Core Team, 2015) and Factor (Lloret, Ferreres, Hernández, \& Tomás, 2017).

\section{Ethical Considerations}

This study was submitted to and approved by the Institutional Review Board and Research Ethics Committee of the Universidade Federal do Espírito Santo, Brazil (protocol number 248.810, CAAE number (38697914.8.0000.5542). All participants were informed about the research objectives and procedures and they consented to participate.

\section{Results}

Data matrix used in the exploratory factor analysis presented an adequate structure to perform the analysis procedures - Bartlett sphericity test was significant $\left(\chi^{2}=1354.68\right)$ and KMO adequacy index value was higher than .79. Horn's parallel analysis and other different criteria (eigenvalues, optimal coordinates, and acceleration factor) were used to guide the decision on the number of factors to be extracted. All which suggested the extraction of two factors.

Exploratory factor analysis was performed using the unweighted least squares method based on a polychromatic correlation matrix (Lloret-Segura, Ferreres-Traver, Hernández-Baeza, \& Tomás-Marco, 2014). The rotation of factors was performed by the Promax method. The extracted items and variance explained for each factor are presented in Table 2.

Table 2

Factorial structure of the adapted SWAM version

\begin{tabular}{ccc}
\hline Item & Anxiety dimension & $\begin{array}{c}\text { Avoidance } \\
\text { dimension }\end{array}$ \\
\hline 1 & $\mathbf{0 . 8 7}$ & 0.02 \\
2 & $\mathbf{0 . 7 8}$ & 0.16 \\
3 & $\mathbf{0 . 7 4}$ & -0.13 \\
4 & $\mathbf{0 7 1}$ & -0.05 \\
5 & $\mathbf{- 0 . 5 5}$ & 0.08 \\
6 & 0.07 & $\mathbf{- 0 . 7 9}$ \\
7 & 0.18 & $\mathbf{- 0 . 6 8}$ \\
8 & 0.20 & $\mathbf{- 0 . 6 4}$ \\
9 & -0.19 & $\mathbf{- 0 . 6 4}$ \\
10 & -0.29 & $\mathbf{0 . 4 8}$ \\
Explained variance & $33.35 \%$ & $26.76 \%$ \\
\hline
\end{tabular}


Items loaded as expected, according to the original scale, that was based on a Canadian sample. The first factor included items associated with anxious attachment dimension, evaluating the individuals' concern and fear of rejection, frustration, and intimacy in relationships with co-workers. The second factor included items associated with avoidant attachment dimension, characterizing the individuals' discomfort with proximity and intimacy in interpersonal relationship with co-workers. This structure was confirmed by a Confirmatory Factor Analysis, performed with the second data sample, carried out using the Maximum Likelihood method. The adjustment indexes indicated good model fit (Table 2): $\chi^{2} / \mathrm{gl}=273$; $\mathrm{CFI}=.96 ; \mathrm{GFI}=.98 ; \mathrm{NNFI}=.94$, RMSEA $=.08(.04-.11)$. The Omega coefficients presented good precision for both factors, anxious attachment at work coefficient was .73 and avoidant attachment at work was .79.

The results of Pearson's correlations evidenced convergent external validity of the Brazilian SWAM version (Table 3).The anxiety dimension of SWAM was positively correlated with the anxiety dimension of the ECR and the SWAM avoidance dimension was positively correlated with the avoidance dimension of the ECR. Both dimensions of SWAM were negatively correlated with satisfaction with life.

Table 3

Correlation matrix among the dimensions of SWAM, ECR and Life Satisfaction (LS) scales

\begin{tabular}{|c|c|c|c|c|c|c|}
\hline Variable & Mean (SD) & 1 & 2 & 3 & 4 & 5 \\
\hline 1. SWAM Anxiety. & $3.03(0.90)$ & 1 & & & & \\
\hline 2. SWAM Avoidance. & $2.26(0.82)$ & 0.00 & 1 & & & \\
\hline 3. ECR Anxiety. & $2.60(0.99)$ & $0.34^{* *}$ & -0.04 & 1 & & \\
\hline 4. ECR Avoidance & $1.76(0.80)$ & $-0.13^{* *}$ & $0.27^{* *}$ & -0.09 & 1 & \\
\hline 5. Life Satisfaction & $4.01(1.14)$ & $-0.15^{* *}$ & $-0.15^{* *}$ & $-0.14^{* *}$ & $-0.25^{* *}$ & 1 \\
\hline
\end{tabular}

\section{Discussion}

This study showed initial evidence of validity and precision of the Short WorkAttachment Measure in a Brazilian sample. Different analysis resulted in adequate indexes to the use of this measure in Brazil. The Brazilian version of the SWAM presented dimensional structure identical to the original version (Leiter, Day, et al., 2015), as well as identical indicators of Omega quality accuracy (Gadermann, Guhn, \& Zumbo, 2012), and expected correlations with convergent constructs (styles of romantic attachment and satisfaction with life). Based on a psychometric point of view, the adapted instrument reached the general expectations for cross-cultural adaptation of a psychological scale (Borsa, Damásio, \& Bandeira, 2012). The Brazilian version of SWAM achieved an adequate adjustment to the factorial procedures performed, as well as congruence of the items with the dimensions of insecure and avoidant attachment of the Canadian version (Leiter, Day, et al., 2015). Also, the Brazilian version of SWAM fit the current theoretical model of attachment measurement applied in self-report scales (Brennan et al., 1998).

The evidence of convergent validity for SWAM, obtained based on correlations with dimensions of romantic attachment, confirms the results presented in the literature which indicate that attachment style tends to be stable throughout life and it also affects different domains of personal life (Hazan \& Shaver, 1990). The results from the correlations reinforce both convergent validity of the instrument and they also demonstrate the attachment styles influence in different areas of life. Moreover, the negative correlations found between insecure attachment styles and life satisfaction confirm some results found in literature and they also suggest that attachment styles have influence in the individuals' health and quality of life (Johnstone \& Feeney, 2015; Thompson, Beauvais, \& Lyness, 1999).

It is important to highlight some limitations of this study. This sample was limited in regarding the participants' age group (most young adults), educational level (incomplete higher education) and Brazilian region (Southeastern). Such concentration impairs the possibility of generalizing the results, considering the extension of the Brazilian territory, as well as the social and cultural variation among different regions. Representative samples of other age groups, socioeconomic classes, educational levels, distinct types of training, positions held in the organization (managerial, operational, strategic) would be necessary to increase the generalization power and also to test the invariance of the scales structure. Another limitation of this study, and also a suggestion for researchers interested in this topic, is the absence of evidence of validity of SWAM by its comparison with other specific constructs in the organizational context, such as job satisfaction, civility, organizational support, engagement at work, and turnover.

The adapted version of the SWAM for Brazil is a significant psychometric instrument to study adult attachment in organizational, work, and career contexts. Although the other measures of attachment adapted to Brazil have presented good indicators of validity and accuracy (Natividade \& Shiramizu, 2015; Rocha et al., 2017; Shiramizu et al., 2013), they are limited by the items nature, which were developed to evaluate romantic or family relationships (Natividade \& Shiramizu, 2015). 
On the other hand, SWAM was specifically developed to assess attachment styles in interpersonal relationships in the workplace. According to Leiter, Day, et al. (2015), there is no consensual evidence of the stability of attachment measures among different domains, i.e., it cannot be asserted that attachment patterns established by instruments specifically developed for a context (for example, romantic attachment) will identify the same patterns when used in another context (for example, at work). Thus, the initial adaptation of SWAM to the Brazilian context may enable Brazilian researchers interested in the attachment construct to investigate this variable specifically at the workplace and its relations with other variables.

In conclusion, we argue that evidence of the psychometric quality of the SWAM was presented, enabling its use in researches on attachment in the organizational context. Worldwide, this construct presents increasing significance in researches that evaluate different topics, which covers interpersonal relationships at work (Byrne et al., 2017; Richards \& Schat, 2011; Yip et al., 2018). The instrument adapted in this study, as well as the attachment theory used for its construction, can contribute to the development of Brazilian studies on interpersonal relationships in the workplace. Especially, it can contribute to understand interpersonal bonding aspects that may predict work performance or that might be central to understand aspects of health, well-being, and quality of life in the workplace.

We suggest that future studies extend the samples assessed, including representatives of other Brazilian states, enabling the creation of interpretative norms based on sex and educational level. Moreover, it is suggested that studies composed of more heterogeneous samples, such as the one performed by Natividade and Shiramizu (2015), regarding different occupations, can test the discriminant potential of the measure. These studies are potentially difficult to perform, for they require a minimum criteria of homogeneity of the sample that allow the assumption of validity evidence for a psychometric instrument (Lloret-Segura et al., 2014; Reppold, Gurgel, \& Hutz, 2014). However, although this study was limited to the assessment of a single sample, its results clearly showed that the adapted SWAM version is adequate for investigations on attachment in the workplace with Brazilian samples.

\section{References}

Borsa, J. C., Damásio, B. F., \& Bandeira, D. R. (2012). Cross-cultural adaptation and validation of psychological instruments: Some considerations. Paidéia (Ribeirão Preto), 22(53), 423-432. doi:10.1590/1982-43272253201314

Bowlby, J. (1973). Attachment and loss: Vol. 2. Separation, anxiety and anger. New York, NY: Basic Books.

Brennan, K. A., Clark, C. L., \& Shaver, P. R. (1998). Selfreport measurement of adult attachment: An integrative overview. In J. A. Simpson \& W. S. Rholes (Eds.), Attachment theory and close relationships (pp. 46-76). New York, NY: Guilford.
Byrne, Z., Albert, L., Manning, S., \& Desir, R. (2017). Relational models and engagement: An attachment theory perspective. Journal of Managerial Psychology, 32(1), 30-44. doi:10.1108/JMP-01-2016-0006

Collins, N. L. (1996). Working models of attachment: Implications for explanation, emotion, and behavior. Journal of Personality and Social Psychology, 71(4), 810-832. doi 10.1037/0022-3514.71.4.810

Collins, N. L., \& Read, S. J. (1990). Adult attachment, working models, and relationship quality in dating couples. Journal of Personality and Social Psychology, 58(4), 644-663. doi: 10.1037/0022-3514.58.4.644

Dunn, T. J., Baguley, T., \& Brunsden, V. (2014). From alpha to omega: A practical solution to the pervasive problem of internal consistency estimation. British Journal of Psychology, 105(3), 399-412. doi:10.1111/bjop.12046

Fraley, R. C., Hudson, N. W., Heffernan, M. E., \& Segal, N. (2015). Are adult attachment styles categorical or dimensional? A taxometric analysis of general and relationship-specific attachment orientations. Journal of Personality and Social Psychology, 109(2), 354-368. doi:10.1037/pspp0000027

Fraley, R. C., \& Shaver, P. R. (2000). Adult romantic attachment: Theoretical developments, emerging controversies, and unanswered questions. Review of General Psychology, 4(2), 132-154. doi:10.1037/1089-2680.4.2.132

Gadermann, A. M., Guhn, M., \& Zumbo, B. D. (2012). Estimating ordinal reliability for Likert-type and ordinal item response data: A conceptual, empirical, and practical guide. Practical Assessment, Research \& Evaluation, 17(3), 1-13. Retrieved from http://pareonline.net/pdf/v17n3.pdf

Garbarino, J. J. (1998). Comparisons of the constructs and psychometric properties of selected measures of adult attachment. Measurement and Evaluation in Counseling and Development, 31(1), 28-45. doi: 10.1080/07481756.1998.12068948

Harms, P. D. (2011). Adult attachment styles in the workplace. Human Resource Management Review, 21(4), 286-296. doi: 10.1016/j.hrmr.2010.10.006

Hatfield, E., \& Rapson, R. L. (2010). Culture, attachment style, and romantic relationships. In P. Erdman \& K.S. Ng (Eds.), Attachment: Expanding the cultural connections (pp. 227-242). New York, NY: Routledge.

Hayden, M. C., Mullauer, P. K., \& Andreas, S. (2017). A systematic review on the association between adult attachment and interpersonal problems. Journal of Psychology \& Psychotherapy, 7(2), 1-9. doi:10.4172/2161-0487.1000296

Hazan, C., \& Shaver, P. R. (1990). Love and work: An attachment-theoretical perspective. Journal of Personality and Social Psychology, 59(2), 270-280. doi:10.1037/0022-3514.59.2.270 
Hesse, E. (1999). The adult attachment interview: Historical and current perspectives. In J. Cassidy \& P. Shaver, (Eds.), Handbook of attachment (pp. 395- 433). New York: Guilford Press.

Johnstone, M., \& Feeney, J. A. (2015). Individual differences in responses to workplace stress: The contribution of attachment theory. Journal of Applied Social Psychology, 45(7), 412-424. doi:10.1111/jasp.12308

Leiter, M. P., Day, A., \& Price, L. (2015). Attachment styles at work: Measurement, collegial relationships, and burnout. Burnout Research, 2(1), 25-35. doi:10.1016/j.burn.2015.02.003

Leiter, M. P., Peck, E., \& Gumuchian, S. (2015). Workplace incivility and its implications for well-being. In P. L. Perrewé, J. R. B. Halbesleben, \& C. C. Rosen (Eds.), Research in occupational stress and well-being: Vol. 13. Mistreatment in organizations (pp. 107-135). Bingley, United Kingdom: Emerald.

Lloret, S., Ferreres, A., Hernández, A., \& Tomás, I. (2017). The exploratory factor analysis of items: Guided analysis based on empirical data and software. Anales de Psicologia, 33(2), 417-432. doi:10.6018/analesps.33.2.270211

Lloret-Segura, S., Ferreres-Traver, A., Hernández-Baeza, A., \& Tomás-Marco, I. (2014). El análisis factorial exploratorio de los ítems: Una guia práctica, revisada $y$ actualizada [The exploratory factor analysis of the items: A practical, revised and updated guide]. Anales de Psicologia, 30(3), 1151-1169. Retrieved from doi:10.6018/analesps.30.3.199361

Natividade, J. C., \& Shiramizu, V. K. M. (2015). Uma medida de apego: Versão brasileira da Experiences in Close Relationship Scale - Reduzida (ECR-R-Brasil) [An attachment measure: Brazilian verion of the Experiences in Close Relationship Scale - Reduced (ECR-R-Brasil). Psicologia USP, 26(3), 484-494. doi:10.1590/0103-656420140086

Poteat, L. F., Shockley, K. M., \& Allen, T. D. (2015). Attachment anxiety in mentoring: The role of commitment. Career Development International, 20(2), 119-132. doi:10.1108/CDI-12-2014-0157

Ramos, K., \& Lopez, F. G. (2018). Attachment security and career adaptability as predictors of subjective wellbeing among career transitioners. Journal of Vocational Behavior, 104, 72-85. doi:10.1016/j.jvb.2017.10.004

R Core Team. (2015). R: A language and environment for statistical computing. Vienna, Austria: R Foundation. Retrieved from http://www.R-project.org/

Ravitz, P., Maunder, R., Hunter, J., Sthankiya, B., \& Lancee, W. (2010). Adult attachment measures: A 25-year review. Journal of Psychosomatic Research, 69(4), 419-432. doi:10.1016/j.jpsychores.2009.08.006
Reizer, A. (2015). Influence of employees' attachment styles on their life satisfaction as mediated by job satisfaction and burnout. The Journal of Psychology, 149(4), 356-377. doi:10.1080/00223980.2014.881312

Reppold, C. T., Gurgel, L. G., \& Hutz, C. S. (2014). $\mathrm{O}$ processo de construção de escalas psicométricas [The process of construction of psychometric scales]. Avaliação Psicológica, 13(2), 307-310. Retrieved from http://pepsic.bvsalud.org/pdf/avp/v13n2/v13n2a18.pdf

Richards, D. A., \& Schat, A. C. H. (2011). Attachment at (not to) work: Applying attachment theory to explain individual behavior in organizations. Journal of Applied Psychology, 96(1), 169-182. doi:10.1037/a0020372

Rocha, G. M. A., Peixoto, E. M., Nakano, T. C., Motta, I. F., \& Wiethaeuper, D. (2017). The Experiences in Close Relationships - Relationship Structures questionnaire (ECR-RS): Validity evidence and reliability. Psico-USF, 22(1), 121-132. doi:10.1590/1413-82712017220111

Shiramizu, V. K. M., Natividade, J. C., \& Lopes, F. A. (2013). Evidências de validade do Experience in Close Relationships (ECR) Inventory para o Brasil [Evidences of validity to the Experience in Close Relationships (ECR) Inventory in Brasil]. Estudos de Psicologia (Natal), 18(3), 457-465. doi:10.1590/S1413-294X2013000300006

Sumer, H. C., \& Knight, P. A. (2001). How do people with different attachment styles balance work and family? A personality perspective on work-family linkage. Journal of Applied Psychology, 86(4), 653-663. doi:10.1037/00219010.86.4.653

Thompson, C. A., Beauvais, L. L., \& Lyness, K. S. (1999). When work-family benefits are not enough: The influence of work-family culture on benefit utilization, organizational attachment, and work-family conflict. Journal of Vocational Behavior, 54(3), 392-415. doi:10.1006/jvbe.1998.1681

Trizano-Hermosilla, I., \& Alvarado, J. M. (2016). Best alternatives to Cronbach's alpha reliability in realistic conditions: Congeneric and asymmetrical measurements. Frontiers in Psychology, 7, 769. doi:10.3389/ fpsyg.2016.00769

Vignoli, E., Croity-Belz, S., Chapeland, V., de Fillipis, A., \& Garcia, M. (2005). Career exploration in adolescents: The role of anxiety, attachment, and parenting style. Journal of Vocational Behavior, 67(2), 153-168. doi:10.1016/j. jvb.2004.08.006

Wachelke, J., Natividade, J., Andrade, A., Wolter, R., \& Camargo, B. (2014). Caracterização e avaliação de um procedimento de coleta de dados online (CORP) [Characterization and evaluation of an online data collection procedure (CORP)]. Avaliação Psicológica, 13(1), 143-146. Retrieved from http://pepsic.bvsalud.org/scielo.php? script $=$ sci arttext\&pid=S1677-04712014000100017 
Yip, J., Ehrhardt, K., Black, H., \& Walker, D. O. (2018). Attachment theory at work: A review and directions for future research. Journal of Organizational Behavior, 39(2), 185-198. doi:10.1002/job.2204

Zanon, C., Bardagi, M. P., Layous, K., \& Hutz, C. S. (2014). Validation of the Satisfaction with Life Scale to Brazilians: Evidences of measurement invariance across Brazil and US. Social Indicators Research, 119(1), 443-453. doi:10.1007/s11205-013-0478-5

Alexsandro Luiz De Andrade is a Ph.D Professor of Psychology at Universidade Federal do Espírito Santo.

Rosana Suemi Tokumaru is a Ph.D Professor of Psychology at Universidade Federal do Espírito Santo.

Michael Leiter is a PhD Honorary Professor, Psychology Department, Deakin University, Geelong, Australia.

Authors' contribution:

Alexsandro Luiz de Andrade substantially contributed to the conception and design of this study, as well as to the analysis and interpretation of data, review and approval of the final version of this paper. Rosana Suemi Tokumaru substantially contributed to the review and approval of the final version of this paper. Michael Leiter substantially contributed to the conception and design of this study. All author assume public responsibility for the content of this paper.

Received: Apr. 09, 2018

1st Revision: Jul. 13, 2018

2nd Revision: Oct. 17, 2018

Approved: Nov. 07, 2018

How to cite this article:

De Andrade, A. L., Tokumaru, R. S., \& Leiter, M. (2020). Preliminary evidence on the validity of the Brazilian Short Work Attachment Measure SWAM Version. Paidéia (Ribeirão Preto), 30 , e3024.doi:https://doi.org/10.1590/1982-4327e3024 